\title{
Dr. Alberto \\ J. Quero \\ OF ALL THINGS SPEAKABLE AND UNSPEAKABLE: KNOWLEDGE AND PARADOXES IN SAINT JOHN OF THE CROSS
}

\author{
Dr. Alberto J. Quero \\ Semiotics Association of Venezuela \\ Calle 70 con Avenida 11, No. 11-38. Sector Tierra Negra. Maracaibo, Venezuela \\ E-mail: ajquero175@gmail.com
}

\section{A bstract}

$\mathrm{T}$

This paper studies eight ascetical poems by Saint John of the Cross, from both a literary point of view and also as an inverse description. Therefore, the paradoxical descriptions of ecstasy and the subsequent acquisition of wisdom become an inverse philosophical reflection. The method of analysis is semiotic and textual interpretative, which renders possible a personal explicative hypothesis. The conclusion is that this work relies on paradox and aporia, which generates "inverse semiosis": signs are not created by what they are, but by what they are not. Although the poems are not always perfect, they reveal a great knowledge of the language. The term "saintjoanine glosa" is proposed for a strophe consisting of nine eight-syllable verses, rhyming A, B, B, A, B, C, D, C, D, which is very infrequent in Spanish poetry. Poetry is, then, extremely efficient in expressing these ambiguities. So literature reaches degree of infiniteness, setting an aesthetic of the impossible and semiotics reaches a crossroad: to be holistic or not to be. We will use our own--and very free---translations into English. Literal equivalence is preferred instead of rhythm and rhyme. In this paper a few Spanish archaisms are kept: spellings as "caça" or "sciencia" have a strictly diachronic value, and meaning is not betrayed if they are written in a modern way. However, updating forms such as "aquesta", which appears in the poem called "Vivo sin vivir en mí" and replacing it by the modern demonstrative "esta" would imply an unacceptable alteration in the syllable structure, that is why it is preserved. In the translations, we have quoted the author's name as "SJC" in order to save space. 


\section{Introduction}

Traditional literary theory gives two basic types of poems: lyrical and narrative (Jahn 2003, 3.2). Saint John's texts seem to resist these categories: they are lyrical because of their subjective nature, but they are also narrative. The fact that the "journey" develops itself towards an ethereal place, does not deny the idea of motion and temporality. We can call Saint John's work a spiritual epopee.

From the philosophical point of view, mysticism, (from the Greek myein 'to close'), can be understood as the soul's astonishment at its divine basis and the experience of infinitude itself, and as the reflection of this experience as an intent of scientific interpretation. That is the reason why he must content himself with an aporia. There is consensus in defining it as "a proposition with no logical end, such as an insuperable logical difficulty" (Ferrater 2000, 34). Müller and Halder (1981) describe the aporia at the last part of problems with multiple favorable solutions. In the poems by Saint John of the Cross, signification derives not from the "positive" attribution of meaning, but precisely from its absence. Saint John ends up defining his spiritual quest as something indefinable. We will dare to call such process as "inverse semiosis". The poet's most important rhetorical resource is "resemantization": the words are given a whole different meaning. Statements like entender no entendiendo 'to understand not understanding' convey much more than a mere incongruity: the poet describes something that appears to be completely absurd; however this idea is perfectly comprehensible for a mystic. Kristeva says that the function of the word is to signify, to make sense and to build knowledge: in every possible utterance, a certain truth underlies; therefore, the language relies on a common knowledge for those who speak, listen, write or read. (Kristeva 1972, 64). Saint John's factual knowledge, nevertheless, is one of impossible transmission. In his poetry, the words have a meaning, but a meaning which is impossible in human terms. If it is true that the poet recodes reality, then reality is heterodox itself.

Consequently, Saint John's poetic recoding starts right in the impossible descriptions. In his works, ecstasy is pleasant by what it ultimately is, the union with God. Ecstasy also includes the pleasure of knowing a different reality. This situation is described on the second strophe of Entreme donde no supe 'I entered where I knew not': De paz y de piedad/ era la ciencia perfecta,/ en profunda soledad/ entendida vía recta 'Of peace and piety / was the perfect science,/ in deep solitude/ was the understood, straight way' (Saint John of the Cross 1991, 56).

Greimas talks about the discourse's 'normal' functioning, in which interpretation and persuasion are linked: interpretation is based on a true knowledge which can be communicated and that the recipient understands it. Therefore, persuasion is very important in the interpretation process (Greimas 1983, 197). As we see, even if Saint John's discourse is perfectly coherent and functional, its content is not: the writer cannot describe what he sees, and the recipient has to verify the experience by himself.

Following Shklovski, Eco says that, in poetry, the disautomatization of language forces to perceive things differently. Besides, semantic continuum can be hypercoded, which generates an excess of expression and contents: there is an aesthetic ambiguity when a deviation in the expression corresponds to an alteration in the contents (Eco 2000, 370). The excessive repetition of the same phrasic segment is one of those deviations in the accepted code patterns; it also increases the information capacity: an ambiguous message becomes auto-reflective. The reader understands that the text is more uncertain than what it seems; the text communicates many things at the same time, it generates its multiple senses due to the free unshackling of semiotic mechanisms (Eco 2000, 378). If this is true, then the author's work is meaningful because of that alteration of contents itself and not just because of its formal perfection. These poems not only de-automatize language, but even reality: only through an astonishing language we can describe an astonishing situation, such as spirituality. In fact, rational knowledge is limited, for it uses lineal thought; but mystical knowledge results from a direct experience which surpasses the intellectual and the sensorial: according to the mystics, sensorial reality can be well perceived but not revealed or communicated through reasoning and common language. Mystical path is, hence, very evasive and not accessible to common knowledge and experience (Spavieri 2005, 30). The obvious 
result is the paradox of the ineffable. The mystic achieves an absolute combination of knowledge and happiness. It does not matter matters if the expressive capacity diminishes ... a poet like ours shows us there is no other way.

\section{Paradox: The Impossible Rep-} resentation.

According to the author, in order to reach ecstasy and knowledge, we must face two great paradoxes. The first one would happen before the ecstasy: life is death and death is not what it seems. The second paradox would happen when the soul tries to obtain the ecstasy and once it has been reached: describing the indescribable.

\subsection{Previous paradox}

In this case, reality is recoded by assigning opposed semantic values to the terms life and death. Life is death, for it delays the union of
God and the human soul. And death is ecstasy, for it makes that union possible. Three poems convey this idea:

\section{a. "Por toda la hermosura" (For all beauty)}

Spanish poetry knows well the glosa, a strophe in which every verse of the initial tercet (an eight-syllable rhyming $\mathrm{X}, \mathrm{A}, \mathrm{A}$ ) functions as a coda for the following strophes. Both the number of verses and the rhyme may vary. The structure of this text is always the same; in the first four or six verses the author sets the poem's mood: he describes a situation that the world comfortably accepts. But in the following two or four verses the poet proposes a variation of the header's last verse and redefines everything. The first three strophes set the poem's philosophical mood. Let us quote the first one:
Sabor de bien, que es finito, /lo más que puedellegar/es cansarelapetito/yestragar el paladar. / Yasi, por toda dulzura /nunca yo me perderé, /sino por un no sé qué /que se halla por ventura (SJC 1991, 59).
'Flavor of good, which is finite/ the most that it can reach/ is to tire the appetite / and destroy the palate/ So, for all sweetness / I will never lose myself, / but for an unknown ${ }^{1}$ thing / that is found by venture'

The other six strophes imply an audience, expressed in a vosotros. So, there is a pedagogic tone; it develops the central premise and is summarized in the last strophe:

No penséis que el interior, / que es de mucha más valía, / halla gozo y alegría / en lo que acá da sabor. / Mas sobre toda hermosura /y lo que es y será y fue, / gusta de un no sé qué/ que se halla por ventura (SJC 1991, 59).

Addressing to a hypothetical audience is a very old resource in Spanish poetry: it is already present in the Poem of Mio Cid. In fact, in ancient times, the fundamental way of literary communication was the public reading or declamation; lyrical poems were sung and epopees were recited (Genette 1970, 55). This means that the text could be both read and performed.

The poem's philosophical core is the duality between the world and the spirit. The word ventura 'venture' does not seem casual. Its obvious meaning is joy; but it also means risk, and chance (Dictionary of the Spanish Royal Academy 2013). Therefore, we notice a phonetic resemblance between the word ventura and the word aventura
'Do not think the interior/ Which is worth much more/ finds bliss and joy / in what here gives flavor / But, instead of all beauty/ and what is, and will be and was/ it likes an unknown thing / that is found by venture'

'adventure'. From the Middle Ages on, semantic games with the word ventura were not strange in Spanish poetry. Later on, the ineffable realities will appear again: "un no sé qué que se halla por ventura" (whose meaning we have already seen) renders to something unnamed but sublime. The paradox consists of this: worldly pleasures are spiritually harmful. What is really tasty is something that does not even have a name and is obtained perilously.

\section{b. "Sin arrimo y con arrimo" (Farther and closer)}

Nine-verse glosas are not so common; other types of glosas, which may have a different number of verses, are more frequent. Up to the XV century, authors such as Manrique, or Guevara

${ }^{1}$ Un no sé qué is a periphrasis which literally means 'an I-don't-know-what'. 
had written poems called esparsas or canciones. But these compositions did not have a theological theme, but a rather gallant one; besides, their rhyme pattern was -almost invariably- ABBACDCDC or ABBACDDCC. In this poem, however, the rhyme is extremely rare: $\mathrm{A}, \mathrm{B}, \mathrm{B}, \mathrm{A}, \mathrm{B}, \mathrm{C}, \mathrm{D}, \mathrm{C}$,
D. Therefore, we propose the term "saintjoanine glosa" for this very unusual rhyme pattern. The entire poem is sustained on oppositions. There is a profoundly teleologic sense, which is expressed on the first verses. The first two strophes explain the contradiction between the world and the soul.
Mi alma está desasida / de toda cosa criada / y sobre sílevantada. / Y en una sabrosavida/sólo en su Dios arrimada (...) / Y aunque tinieblas padezco/ en esta vida mortal / no es tan crecido mi mal, / porque, si de luz carezco / tengo vida celestial (SJC 1991, 54).
'My life is detached / from all created things / and stands up on itself / And in a delightful life/ only to its God it approaches/ ... And although obscurity I suffer / in this mortal life/ my evil is not so big / for, if I lack of light / I have celestial life'.

in words the confluence of the opposites in the soul's innermost core (Biedermann 1996, 93). Consolidating the poem's teleological sense, the third strophe resolves the contradiction previously set: expression of ineffable things, which eyes cannot perceive and the mystic cannot distinguish from dazzling light", an idea which tries to capture

Hace talobra el amor / después quele conocí, que si hay bien o mal en mí / todo lo hace de un sabor / y al alma transforma en sí. / Y, así, en su llama sabrosa / la cual en mí estoy sintiendo / apriesa, sin quedar cosa / todo me voy consumiendo (SJC 1991, 54).
'Such work love makes / after I knew it/ that if there is good or evil in me / it makes all taste the same / and it transforms the soul in itself. / So, in its delightful flame / which I feel inside of me / quickly, without any remain / I consume myself completely'

\section{c. "Vivo sin vivir en mí" (I live without living in me).}

In this glosa, the last two verses are paired, rhyming in -ero. The seventh and eight strophes are the core of the poem: true. The soul must meet God in another plane; the soul must come close (arrimarse) to God's love, which is described by another contradiction: 'delightful flame'.

Sácame de aquesta muerte, / mi Dios, y dame la vida;/ no me tengas impedida/ en este lazo tan fuerte; / mira que peno por verte / y mi mal es tan entero / que muero porque no muero / Lloraré mi muerte ya / y lamentaré mi vida / en tanto que detenida/ por mis pecados está. / iOh, mi Dios! ¿cuándo será/ que yo diga de vero / vivo ya porque no muero. (SJC 1991, 50).

Despite the author is a man, we find feminine participles, for the narrator of the poem is the soul, which is a feminine word in Spanish: alma, 'soul'. As it happens in the previous poem, the
'Take me out of this death, / my God, and give me life; / do not have me constrained/ in this so tight bond; / see how I suffer willing to see you/ and my pain is so terrible/ that I die because I do not die/ I will cry my death now / and I will lament my life / for stopped/ due to my sins it is. / O, my God!, when will it be / that I may for real say / I live now because I do not die?'

soul finds that life without God is intolerable, and wishes it all to end in order to go to Heaven. Again, the teleological idea: everything will be solved at the end, when the true happiness can 
be reached. We may deduce a connection with Saint Francis of Assisi: the well-known "Prayer for peace" ends saying "dying in You [God] we are born to eternal life"

\section{d. "Para venir a gustarlo todo" (To come and taste it all)}

This poem has an uneven syllable structure, but the rhyme is perfectly consonant. This poem is the most paradoxical of all. From the first pair of verses on, the poet describes the irreductible conflict the mystic must face: Para venir a gustarlo todo / no quieras tener gusto en nada to come and taste it all / do not want to enjoy any- thing' (SJC, 1993, 89). There is a key expression, founded on a semantic game. Spanish verb gustar means 'to taste,' but also 'to like.' Therefore, it conveys a double signification: in order to experience, we must forget earthly pleasures. Noun todo 'all' alludes unity. For the spirit, joy and wholeness are the same thing. The expression no tengas gusto en nada 'you must not have pleasure in anything' implies the denying of the world and its links. At the end, the dramatic core appears. It follows the same both the logical and the formal patterns the aforementioned verse had set:
Para venir a donde no sabes / has de ir por donde no sabes; / para venir a lo que no posees / has de ir por donde no posees; / para venir a lo que no eres / has de ir por donde no eres (SJC 1993, 89).
'Take me out of this death, / my God, and give me life; / do not have me constrained/ in this so tight bond; / see how I suffer willing to see you/ and my pain is so terrible/ that I die because I do not die/ I will cry my death now / and I will lament my life / for stopped/ due to my sins it is. / O, my God!, when will it be / that I may for real say / I live now because I do not die?'

This text has an evident Christian basis: the idea of self negation appears in Matthew 8:34 and in Luke 9:23. Self-denying is proposed even in the ontological level: stop being what one is and walking a path where one is nothing. Worldly safety must be abandoned in order to reach an unknown but transcendent reality, one which words cannot properly describe.

\section{Posterior Paradox}

Posterior paradox is the most meaningful of the two kinds. This one introduces the problem of the ineffable. Four poems fall in this category. There are two thematic possibilities: (1) poems which talk about the "journey" (the process which leads the soul to the contemplation of divinity). And (2) poems which talk about the "arrival" (ecstasy itself and what makes indescribable).

\section{a. "Tras un amoroso lance" (After a loving affair).}

The poems talks about the journey. The first strophe takes the idea of revelation through subjectivity rather than reason:
Para que yo alcance diese / a aqueste lance divino / tanto volar me convino / que de vista me perdiese. / Y, con todo, en este trance / en el vuelo quedé falto / mas el amor fue tan alto / que le di a la caza alcance (SJC 1991, 52).

Ordinary judiciousness is insufficient if we want to reach the ultimate joy and wisdom. The cause that leads to knowledge was ineffable in "Por toda la hermosura", but in this poem has a name: love. Mancho (2012) says the image of flight, frequent in Christian symbolism, is associated with the axis of verticality; so the ideas high and low are opposed, they have different mystical and moral connotations. Surprisingly, the author inverts the meaning: the soul must
'In order for me to reach / this divine affair/ flying was so convenient for me/ that I should be out of sight/ Yet in this trance / I lacked flight / but love was so high/ that I caught the prey.'

lessen itself in order to fly. With this first paradox, he achieves dramatic expressiveness: the more one wishes to know God through habitual ways, the more difficult such task becomes. It is necessary, to abandon that purpose and to think of contemplation as the sole way to reach God. The ecstasy-knowledge is only acquired when the earthly ego is annihilated. The second strophe deepens in that idea: the "conquest" is made in the dark, and it is the result of love: 
Cuanto más alto subía / deslumbróseme la vista / Y la más fuerte conquista / en oscuro se hacía. / Mas, por ser de amor el lance, / di un ciego y oscuro salto / y fui tan alto, tan alto / que le di a la caza alcance / Cuanto más alto llegaba / de este lance tan subido 1 / tanto más bajo y rendido / abatido me hallaba. / Dije: no habrá quien alcance. / $Y$ abatime tanto, tanto / que fui alto, tan alto / que le di a la caza alcance (SJC 1991, 52).

Darkness is here a sign of intimacy; and blindness is a sign of the unconditional. Therefore, two semantic recodings are produced, and a euphoric emphasis is added: in order to attain the ecstasy-knowledge, love must be unrestricted. This idea will be developed in the third strophe, almost a replica of the previous one. The terms related to elevation are associated to spiritual realities, which can be obtained only after a big effort; the terms associated with

Por una extraña manera / mil vuelos pasé de un vuelo / porque esperanza de cielo / tanto alcanza cuanto espera. / Esperé solo este lance / y en esperar no fui falto, / pues fui tan alto, tan alto / que le di a la caza alcance (SJC 1991, 52).

The poet talks three times about catching a prey. Number three has a profound meaning: it represents the triad, the synthesis and the perfection; that is whynumber three represents the Most Holy Trinity within the Christian symbolism (Biedermann 1996, 327). The first three strophes have the same structure: the poet talks about a flight (a rational attempt to comprehend) which is in vain. But the soul obtains its goal through a subjective element. In the first strophe, that element has been called "love," in the second one it has been called "blind love" and in the third strophe it is expressed in the idea of lessening. The "blind flight" could well be a predecessor of Kierkegaard's "leap of faith."

iOh, noche que guiaste! / iOh, noche amable más que la alborada!/... Quedeme y olvideme, / el rostro recliné sobre el Amado. / Cesó todo y dejeme / dejando mi cuidado / entre las azucenas olvidado (SJC 1991, 92).
'As I soared more / my sight was blinded / And the toughest conquest / in the dark was made / But, being of love the affair/ I took a blind and obscure jump / and I soared so high, so high / that I caught the prey/ The higher I arrived / in this elevated affaire/ the lower, the more surrendered/ and lessened I found myself / I said: there will not be anyone able to reach / And I lessened myself so much / that I soared so much, so much / that I caught the prey.'

descending refer to spiritual desolation. There is a paradox, it is almost impossible to represent by other means different to poetry: to lower oneself in order to soar.

In the second strophe, another paradox is produced: This paradox is also teleological: waiting to receive. The soul must wait in order to acquire and "pass a thousand flights in a single flight": it is the ultimate attempt to get what one seeks and cancel all the previous labors

'By a strange way / a thousand flights I quickly flew / because the hope for Heaven / the more it reaches the more it waits. / I waited alone in this trance / and I lacked not waiting / for I went so high, so high, / that I caught the prey.'

\section{b. "Noche oscura" (Dark night).}

This poetic structure is called lira. The first two strophes (which virtually clone one another) establish the prolegomena of revelation: it is night time, everything is silent and dark. And idea is developed through two repetitive elements: (1) in both strophes, the third verse is a vocative interjection, and (2), the last verse emphasizes the space of quietness. Third and fourth strophes recount the discovery of inner light and how it guides the narrator to find an anonymous character in an unnamed place. The four final strophes clearly define the ecstasyknowledge. The dramatic core is:
'O night, that guided [me]! / O night, more lovely than dawn! /... I stayed and forgot about myself, / the visage I reclined on The Loved One / Everything ceased and I abandoned myself / leaving my concerns/ forgotten among the lilies'

\footnotetext{
1 Another semantic game: Spanish word subido means both "high" and "important"

2 A word game which is impossible to translate: Spanish word vuelo means flight. But the popular expression de un vuelo (lit., "in a single flight") means quickly and effortlessly.
} 
The tone is openly mystical and there could be some esoterical allusion in the metaphor of the "secret scale". There is an unequivocal contrast between the night-time darkness and the lighting within the narrator's soul. In the two first strophes, we find the image of the house. If it could well mention a real house, this image has strong connotations: it is a "symbol of man himself, who has found his enduring place in cosmos" (Biedermann 1996, 93).

In the third and fourth strophe there are many paradoxes. Firstly, the antinomy between external darkness and inner light is set, being the latter a metphor of faith. The chromatic contrast is also meaningful: while the outside (tangible world) is inert and passive, the world of feelings is alive and shiny. Secondly, semiosis of spirituality appears once more: the "other", the one whom is to be met, lacks a name; nonetheless he is well known by the narrator.

\section{c. "Entreme donde no supe" (I entered where I knew not).}

Another glosa which opens with a tercet (eight-syllable rhyming $\mathrm{X}, \mathrm{A}, \mathrm{A}$ ), whose last verse will repeat itself as a refrain. This lengthy text develops a central premise: the access to the divine. In the first strophe, the "journey" is settled on

'I knew not where I entered / but when I saw myself there / without knowing where I was/ big things I understood/ I will not say what I felt:/ that I ended up knowing / all science transcending.'

(SJC 1991, 56).

These eight verses portray the main notion in Saint John's poetry: the ecstasy-knowledge and the difficulty to express it. Once the journey is over, the arrival is described profusely: the poem's dramatic core lays in the revelation: the knowledge of God is the goal of any spiritual quest. The representation is impossible: the au- thor defines the situation as indefinable. He can give testimony of the experience, but he cannot say what exactly it consists of, for there are no words to depict it. From the second strophe on, the poet tries to illustrate his rapture: he develops a central premise and recapitulates the elements he had previously drafted:
Estaba tan embebido, / tan absorto $y$ enajenado, / que se quedó mi sentido / de todo sentir privado / y el espíritu dotado / de un entender no entendiendo / toda ciencia trascendiendo (SJC 1991,56).
'I was so immersed, / so absorbed and distracted, / that my sense was / of all feeling deprived / and the spirit was given / an understanding not understanding / and all science transcending'
The final strophe has a pedagogical tone. Again he addresses himself to implied listeners, figured in a vosotros. The symbol of the cloud appears: Cuanto más alto se sube/ tanto menos se entendía,/ que es la tenebrosa mube / que a la noche esclarecia 'the higher one climbs / the less one understands / that is the tenebrous cloud / that cleared the night.' Besides setting a relation with the height, where Divinity dwells, the cloud is a "paradoxical image which tries to capture with words the confluence of the opposites in the bottom of being" (Biedermann 1996, 337).

Another theme reappears: the elimination of ego in order to be worthy of knowledge: quien se supiere vencer / con un no saber sabiendo / irá siempre trascendiendo 'he who knows how to defeat himself / with a knowing not knowing / will always transcend'. Deeply rooted in Christian symbolic tradition, it alludes humbleness and effort as keys to revelation.

\section{d. "Llama de amor viva" Living flame of love.}

Among the many kinds of Spanish lyrical poems, an estancia is one of the most difficult: the third and the sixth verses have eleven syllables and all the remaining verses have seven syllables; hence, an extraordinary ability is required. Saint John's text is fully symmetrical. The use of the oxymoron is rather frequent; vocative exclamations are meant to create intensity: 
iOh cauterio suave! / iOh regalada llaga! / iOh mano blanda! iOh toque delicado! / que a vida eterna sabe / y toda deuda paga. / Matando, muerte en vida has trocado (SJC 1991, 94).

The general tone is completely ecstatic. Once again the poet recodes the ideas of life and death. This procedure finishes in the second strophe, and from there on, all the vocatives are meta-

iOh lámparas de fuego / en cuyos resplandores / las profundas cavernas del sentido, / que estaba oscuro y ciego, / con extraños primores / calory luz dan junto a su querido! (SJC 1991, 94).

Concepts of time and space are abolished within the text. This is explainable: for the mystic, the true unity, which is the essence of life or the essence of things, will only be perceived when he discovers the interrelations between time and space and transcends them. Such goal can only be achieved by a shift in the level of consciousness, and not through scientific and intellectual ways (Spavieri 2005, 50). According to the author, ecstasy is awareness and vice-versa. Everything mixes in a single cluster, the union with God.

\section{Conclusion.}

Saint John's poetry tries to represent transcendence, even in absentia; this appears to be impossible, but it is not. If Saint John's poems are not always perfect in rhyme and structure, they always are composed with great knowledge of the Spanish language, and show the author's poetic abilities. That is how we discover the writer's mystical philosophy and how it matches his poetic creations. Firstly, by reading these texts we can infer his theory of ascesis: (1) There is an unsolvable opposition between earthly life and spiritual life. (2) Man is confined -although only temporarily- to the material world; the impossibility of immediate access to the presence of God is the greatest conceivable pain. And (3), through persistent spiritual exercises, the devout soul can eventually meet God.

Secondly, we realize that Saint John's poetry is founded on the ascesis. However, the poet's predicament is not spiritual, but expressive. He admits he cannot describe adequately the situations he witnesses, so the impossibility to signify transcendent realities becomes the very core of his works. This amazement has two basic features: (1) Uselessness of sensorial perception and a disdain towards rationality. And (2), joyful acquisition of a complete but ineffable wisdom.
'O soft burning! / O delicious wound! / O smooth hand! O delicate touch!/ that tastes like eternal life and all debts pays. / Killing, death in life you have swapped'

phors which emphasize the euphoric tone. Unlike "Tras un amoroso lance," in this poem, the author reconsiders the traditional association between blindness, darkness and ignorance:

'O lamps of fire! / in whose splendors/ the deep caverns of sense, / that was obscure and blind / with strange delights / heat and light have, next to the loved one'

Consequently, Saint John's poetry generates a paradoxical semiosis: its meaning lays not in what is said but in what is not. In fact, these texts do not define "positively" what the author experienced, but exactly its antonym: the unutterable and the subsequent astonished pleasure. The process of signification follows an inverse direction, one which is on the very edge of common logic; it is, however, completely valid for the mystic. This leads to the "essential hypothesis" Fabbri (2004) proposes: one must not think there are objects but things: "organic arrangements of shapes and substances." Then, the text cannot be dismantled in minimal semiotic units; instead, one must create "universes of articulated meanings" in order to reconstruct specific sense organizations within those universes (Fabbri 2004, 41). And this is what has happened here: just like silence is vital for music, the author shows us that the unspeakable has a place in literature, for there are some realities which are very meaningful but cannot be described accurately: spiritual matters can only be explained through paradoxes... which is a paradox in itself. The "degree zero of writing" (Barthes 2005, 79) would be the one which sums the total content of the words and allows them to be received as something absolute but accompanied by all its possibilities. But perhaps Saint John inaugurates the infinite degree of poetry: if the poetic word has an unexpected form, "like a Pandora's box where all language categories appear from" (Barthes 2005, 179), then Saint John's poetry is infinite just because it runs out of words: states of the soul and invisible realities are so extraordinary that art lives on the very edge of feasibility. Its beauty is the writer's own amazement before what his soul can comprehend, but his speech cannot describe. 


\section{REFERENCES:}

1. Biedermann Hans. Diccionario de símbolos. Barcelona: Paidós. 1996.

2. Spanish Royal Academy. Diccionario de la Real Academia de la Lengua Española. 2013 Web: www.rae.es (date of access: April 12, 2015)

3. Eco, Umberto. Tratado de semiótica general Barcelona: Lumen. 2000.

4. Fabbri Paolo. El giro semiótico. Barcelona: Gedisa. 2000.

5. Ferrater Mora José. Diccionario de filosofia. Buenos Aires: Editorial Sudamericana. 2000.

6. Greimas Algirdas J. La semiótica del texto. Barcelona: Paidós. 1983.

7. Jahn Manfred. Poems, Plays, and Prose: A Guide to the Theory of Literary Genres. English Department, University of Cologne. Version 1.7. 2003.

8. Kristeva Julia. La productividad llamada texto, in Lo verosímil, ed. Roland Barthes. Buenos Aires: Tiempo Contemporáneo. 1972.
9. Mancho Duque María Jesús. Aproximación lexical a una imagen sanjuanista: el vuelo. 2012.

10. http://bib.cervantesvirtua l.com/servlet/SirveObras/ p291/01371418988929698570035/index. htm (date of access: April 12, 2015)

11. Mueller Max and Alois Halder. Breve diccionario de filosofia. Barcelona: Herder. 1981.

12. Ruiz Federico. General Introduction to the Complete Works of Saint John of the Cross. Madrid: Editorial de Espiritualidad. 1993.

13. Saint John of the Cross. Poesía. Caracas: Monte Ávila. 1991.

14. Saint John of the Cross. Obras completas. Madrid. Editorial de Espiritualidad. 1993.

15. Genette Gérard. In Estructuralismo y literatura, ed. José Sazbón. Buenos Aires: Ediciones Nueva Visión. 1970.

16. Spavieri Gianfranco. Los fragmentos del arco iris. Mérida: Universidad de Los Andes. 2005 . 